\title{
IDEOLOGI PENERJEMAH DALAM TERJEMAHAN KATA TABU PADA FILM 22 JUMP STREET
}

\author{
Muhammad Arif M.R. Nababan Riyadi Santosa \\ Universitas Sebelas Maret \\ syarifoji@gmail.com
}

\begin{abstract}
This research aims to discover the ideology of the translator in translating taboo words in 22 Jump Street. In collecting the data, the researchers used a criterion-based sampling technique, and then continued to analyze the techniques used by the translator in order to find out the translator's ideology. The result of this research shows that the ideology of the translator is domestication, which indicates the tendency of the translator to delete the taboo words in his translation. At the same time, the translator also tried to find the equivalence of the taboo words in the target language.
\end{abstract}

Keywords: translation, ideology, taboo words

\begin{abstract}
Abstrak
Penelitian ini bertujuan untuk menemukan ideologi penerjemah dalam menerjemahkan kata-kata tabu dalam film 22 Jump Street. Peneliti mengumpulkan data linguistik dengan menggunakan teknik criterion-based sampling dan kemudian dilanjutkan dengan menganalisis teknik penerjemahan yang digunakan penerjemah agar ideologi penerjemah dapat ditentukan. Temuan penelitian ini mengungkapkan bahwa ideologi penerjemah pada penelitian ini adalah domestikasi (pelokalan), sebagai akibat dari adanya kecenderungan penerjemah untuk menghilangkan kata tabu dalam karya terjemahannya. Di saat yang sama, penerjemah mencari padanan kata tabu pada bahasa sasaran.
\end{abstract}

Kata kunci: penerjemahan, ideologi, kata tabu

\section{PENDAHULUAN}

Peran penerjemah dalam penerjemahan adalah vital. Penerjemah menjadi orang yang bertanggung jawab untuk menyampaikan pesan penulis kepada pembaca yang memiliki perbedaan bahasa dan budaya di antara keduanya. Penerjemah menjadi penghubung bagi perbedaan yang ada antara penulis dan pembaca. Tidak hanya memastikan pesan dari penulis tersampaikan secara utuh, dalam artian tidak ada pesan yang ditambah ataupun dikurangi, penerjemah juga harus memperhatikan aspek lain. Nababan dkk (2012) menyatakan bahwa ada tiga aspek yang menjadi perhatian penerjemah, yakni keakuratan, keberterimaan, dan keterbacaan. Oleh karena itu, selain mengalihkan pesan dari bahasa penulis ke bahasa pembaca, penerjemah juga harus mempertimbangkan apakah pembaca terbiasa dengan tata bahasa dan penggunaan ungkapan yang diterjemahkannya serta mempertimbangkan apakah pembaca mampu memahami dengan baik teks karya terjemahannya.

Untuk memenuhi ketentuan tersebut, Bell (1991) menyatakan bahwa ada empat kompetensi yang harus dimiliki oleh seorang penerjemah. Kompetensi pertama adalah gramatika yang berkaitan dengan pengetahuan kaidah bahasa yang meliputi kosakata, 
pembentukan kata, pelafalan, dan struktur kalimat. Kompetensi kedua adalah sosiolinguistik yang berkaitan dengan pengetahuan dan kemampuan untuk menghasilkan dan memahami tuturan yang sesuai dengan konteks. Kompetensi ketiga adalah wacana yang berkaitan dengan kemampuan menggabungkan bentuk dan makna untuk menghasilkan teks tulis dan lisan yang padu. Kompetensi keempat adalah penguasaan strategi komunikasi dan hal-hal lain yang mendukung proses penerjemahan.

Tiap-tiap penerjemah memiliki ideologi yang ia pegang dalam setiap proses penerjemahan yang dilakukannya, tentang cara yang dipilihnya untuk menerjemahkan, diksi yang dipilihnya untuk menggantikan kata dari bahasa sumber ke bahasa sasaran, dan pilihanpilihan lain yang bisa muncul saat ia menerjemahkan. Hoed (2006) menjelaskan bahwa ideologi merupakan prinsip atau keyakinan tentang benar-salah dan baik-buruk atau dengan kata lain, ideologi merupakan sesuatu yang dianggap benar atau salah, baik atau buruk oleh seseorang. Dalam penerjemahan, terdapat dua kutub ideologi sebagaimana yang diungkapkan oleh Venuti (1995), yaitu ideologi pengasingan dan pelokalan. Penerjemah yang menganut ideologi pengasingan cenderung berpihak pada bahasa sumber, yakni mempertahankan aturan dan kaidah dalam bahasa sumber, misalnya tata bahasa, diksi, bahkan nilai budaya yang terkadung di dalam teks tersebut tanpa mempertimbangkan apakah nantinya karya terjemahannya dapat diterima dengan baik oleh pembaca di bahasa sasaran (Mazi-Leskovar, 2003). Sementara itu, penerjemah yang menganut ideologi pelokalan cenderung menyesuaikan penyampaian pesan yang ingin disampaikan penulis menggunakan gaya bahasa dan budaya yang berlaku pada bahasa sasaran.

Untuk menilai ideologi penerjemah, peneliti dapat menggunakan karya terjemahan seorang penerjemah sebagai bahan acuannya. Penentuan ideologi seorang penerjemah dimulai dari menilai unit mikro dari terjemahannya, yaitu kata dan frasa. Kata dan frasa dari bahasa sumber dibandingkan dengan kata dan frasa pada bahasa sasaran guna mengetahui teknik penerjemahan yang digunakan. Teknik penerjemahan, menurut Molina dan Albir (2002), adalah cara yang digunakan penerjemah untuk menyepadan istilah yang ada pada bahasa sumber dengan istilah pada bahasa sasaran. Setelah penilaian pada unit mikro selesai dilakukan, penilaian dilanjutkan ke tingkat makro, yaitu teks. Penilaian tingkat makro ini disebut metode penerjemahan. Metode penerjemahan ditentukan dengan menyimpulkan kecenderungan teknik penerjemahan yang digunakan. Newmark (1988) mengemukakan delapan metode penerjemahan dan membaginya menjadi dua arah kecenderungan, yaitu kecenderungan pada bahasa sumber dan kecenderungan pada bahasa sasaran. Setelah metode penerjemahan ditentukan, ideologi penerjemah dapat dilihat ke arah mana, apakah pelokalan atau pengasingan. Selain dapat dinilai dari teks terjemahan secara keseluruhan, ideologi penerjemah juga dapat dinilai per bagian teks, misalnya pada kelompok ungkapan atau kumpulan kata tertentu. Dalam penelitian ini, peneliti menentukan satu fokus, yaitu pada penerjemahan kata tabu untuk membatasi penelitian agar tidak meluas.

Kajian penerjemahan yang berkaitan dengan kata tabu telah banyak dilakukan. Yamayanti (2015) meneliti kata tabu dalam film Ted serta mengkaji teknik penerjemahan yang digunakan penerjemah guna menemukan padanan kata tabu dari bahasa Inggris ke bahasa Indonesia. Ia menemukan sembilan kategori kata tabu, yaitu cursing, profanity, taboo, obscenity, vulgarity, slang, epithet, insult dan slurs, serta scatology. Teknik penerjemahan yang ditemukan dalam kajiannya ada dua, yakni penerjemahan literal dan idiomatik.

Kusmayani (2013) mengkaji terjemahan istilah tabu dalam film The Hurt Locker. Dalam penelitiannya, ia mengkaji teknik penerjemahan apa saja yang digunakan oleh 
penerjemah dalam menerjemahkan istilah tabu dalam film tersebut. Kusmayani menemukan tujuh teknik penerjemahan, yaitu similar expressive meaning, omission/deletion, generalization, interjection, less exprssive meaning, reduction, dan borrowing. Penggunaan teknik penerjemahan tersebut berpengaruh pada kualitas terjemahannya. Tingkat keakuratan terjemahan istilah tabu dalam film tersebut menunjukkan hal yang positif. $78 \%$ data dinilai akurat, sedangkan hanya $18 \%$ data dinilai kurang akurat dan $4 \%$ data dinilai tidak akurat. Dari aspek keberterimaan, terjemahan istilah tabu dalam film tersebut juga mendapat nilai yang baik. Sebanyak 91\% data dinyatakan berterima dan 9\% data dinyatakan kurang berterima.

Sejalan dengan Kusmayani (2013) dan Yamayanti (2015), Shanti (2014) juga mengkaji teknik penerjemahan kata tabu dalam film. Akan tetapi dalam hal ini, Shanti menggunakan dua film sebagai sumber data, yaitu The Fast and Furious Tokyo Drift dan Fast Five. Dari sumber data tersebut, Shanti menemukan 39 ekspresi kata tabu yang diklasifikasikan ke dalam sembilan kategori kata tabu. Sementara itu, teknik penerjemahan yang ditemukan ada dua, yaitu literal dan nonliteral.

Jika tiga penelitian sebelumnya mengaitkan kata tabu dengan teknik penerjemahan, hal yang berbeda justru dilakukan Pratama (2016). Pratama menganalisis tujuan penggunaan kata tabu dalam film The Help dan mengaitkannya dengan strategi penerjemahan. Dalam penelitiannya, dia menemukan bahwa setidaknya terdapat 16 tujuan pengungkapan kata tabu dan tiga strategi yang digunakan penerjemah dalam menerjemahkan kata tabu tersebut dari bahasa Inggris ke dalam bahasa Indonesia, yaitu transfer, euphemism, dan omission.

Permadi (2017) juga menganalisis strategi penerjemahan kata tabu dalam film. Dia menggunakan film SpongeBob Movie Sponge Out of Water sebagai sumber data. Lebih lanjut, Permadi juga mengaitkan penggunaan strategi penerjemahan dengan kualitas terjemahan meski tidak memaparkan data kualitas terjemahannya dalam bentuk angka.

Dari penelitian-penelitian di atas, dapat dilihat bahwa kajian terjemahan kata tabu masih terbatas pada tingkat teknik dan strategi penerjemahan, artinya penelitian-penelitian tersebut masih berkecimpung pada penilaian level mikro. Oleh karena itu, peneliti melakukan penelitian ini untuk menilai terjemahan ke tingkat yang lebih tinggi, yaitu level makro, menilai metode penerjemahan dan menentukan ideologi penerjemah yang dalam hal ini dibatasi hanya pada terjemahan kata tabu.

\section{METODE}

Penelitian ini merupakan penelitian kualitatif deskriptif karena data dalam penelitian ini berupa kata serta data dijelaskan sebagai sebuah fenomena. Data dalam penelitian ini terbagi menjadi dua bagian, yaitu data linguistik dan penerjemahan. Data linguistik adalah kata-kata tabu yang bersumber dari dokumen, dalam hal ini adalah subtitle (teks terjemahan) film 22 Jump Street versi bahasa Inggris, sedangkan data penerjemahan adalah teknik penerjemahan, metode penerjemahan, dan ideologi penerjemah yang diperoleh dengan cara membandingkan subtitle film 22 Jump Street versi bahasa Inggris dengan versi bahasa Indonesia.

Film 22 Jump Street dipilih sebagai sumber data karena film ini mendapat penilaian cukup baik di beberapa survei penilaian film, di antaranya laman rottentomatoes.com memberi nilai $85 \%$ dan laman metacritics.com memberi nilai $71 \%$. Selain itu, setelah dilakukan observasi awal, dalam film ini juga banyak terdapat kata tabu yang muncul sehingga ketersediaan data untuk penelitian ini dapat terpenuhi. 
Subtitle film 22 Jump Street versi bahasa Indonesia yang dipilih sebagai sumber data adalah subtitle versi amatir yang diunduh pada laman subscene.com. Subtitle ini dibuat oleh pengguna dengan nama pengguna FatHur. Subtitle ini dipilih karena mempertimbangkan penilaian dari pengguna pada laman subscene.com, yaitu 9/10 dengan rincian 337 pengguna memberikan penilaian baik dan hanya satu pengguna yang memberikan penilaian buruk. Selain itu, subtitle ini juga telah diunduh sebanyak 97.541 kali.

Data linguistik penelitian ini dikumpulkan menggunakan teknik purposive sampling atau teknik criterian-based sampling. Kriteria yang digunakan sebagai dasar pengumpulan data linguistik adalah enam kategori kata tabu yang dicetuskan oleh Wardhaugh (2006), yaitu kata tabu yang berkaitan dengan seks, ekskresi, politik, kematian, agama, dan anggota dan fungsi tubuh.

Setelah data linguistik terkumpul, data tersebut dianalisis menggunakan teknik analisis isi dengan membandingkan data tersebut dengan subtitle versi bahasa Indonesianya guna mengetahui teknik penerjemahan yang digunakan penerjemah. Teknik terjemahan yang digunakan sebagai acuan berasal dari Molina \& Albir (2002) yang meliputi delapan belas teknik penerjemahan, yaitu adaptasi, amplifikasi, peminjaman, kalke, kompensasi, deskripsi, kreasi diskursif, kesepadanan lazim, generalisasi (dalam beberapa kasus berlaku implisitasi), partikularisasi (dalam beberapa kasus berlaku eksplisitasi), amplifikasi linguistik, kompresi linguistik, harfiah, modulasi, transposisi, reduksi/delesi, substitusi, dan variasi.

Metode penerjemahan dari terjemahan subtitle film 22 Jump Street ini disimpulkan setelah data teknik penerjemahan diperoleh yang kemudian dilanjutkan dengan menentukan ideologi penerjemahannya.

Untuk memastikan validitas data dalam penelitian ini, peneliti melakukan triangulasi sumber data dan metode. Sumber data penelitian ini, selain berupa dokumen, yakni subtitle film 22 Jump Street, informan juga menjadi sumber data yang berlaku sebagai penilai untuk memastikan data linguistik yang telah dikumpulkan peneliti memenuhi kriteria yang ada serta menganalisis teknik penerjemahan yang terjadi setelah membandingkan subtitle film 22 Jump Street versi bahasa Inggris dengan bahasa Indonesia. Pada tahap pengumpulan data, peneliti menggunakan purposive sampling dengan teknik criterian-based sampling berdasarkan teori kata tabu Wardhaugh (2006), lalu teknik analisis isi berdasarkan teori teknik penerjemahan dari Molina dan Albir (2002), serta melakukan focus group discussion dengan para informan.

\section{TEMUAN DAN PEMBAHASAN}

Setelah data linguistik dikumpulkan, peneliti memperoleh data sebagai berikut.

Tabel 1. Perolehan Data Kata Tabu pada Film 22 Jump Street

\begin{tabular}{llccc}
\hline \hline No & & Kategori & Jumlah & Persentase \\
\hline 1 & Seks & & 100 & 62,5 \\
\hline 2 & Ekskresi & 41 & 25,6 \\
\hline 3 & Fungsi dan & Anggota Tubuh & 12 & 7,5 \\
\hline 4 & Agama & & 7 & 4,4 \\
\hline \multicolumn{2}{r}{} & Total & $\mathbf{1 6 0}$ & $\mathbf{1 0 0}$ \\
\hline \hline
\end{tabular}


Dari Tabel 1, dapat dilihat bahwa kata tabu yang berhubungan seks muncul sebanyak 100 kali atau $62,5 \%$ dari keseluruhan data. Kata tabu yang berhubungan dengan ekskresi muncul sebanyak 41 kali dengan persentase $25,6 \%$. Sementara itu, kata tabu yang berhubungan dengan fungsi dan anggota tubuh serta kata tabu yang berhubungan dengan agama masingmasing sebanyak 12 dan 7 kali dengan persentase 7,5\% untuk kata tabu yang berhubungan dengan fungsi dan anggota tubuh serta 4,4\% untuk kata tabu yang berhubungan dengan agama.

Penelitian kemudian dilanjutkan dengan menganalisis teknik penerjemahan yang digunakan penerjemah dengan cara membandingkan kata tabu versi bahasa Inggris dengan versi terjemahan bahasa Indonesianya. Dari analisis tersebut, diperoleh data sebagai berikut.

Tabel 2. Data Teknik Penerjemahan pada Kata Tabu yang Berhubungan dengan Seks

\begin{tabular}{llcc}
\hline \hline Kategori & \multicolumn{1}{c}{ Teknik Penerjemahan } & Jumlah & Persentase \\
\hline \multirow{5}{*}{ Seks } & Delesi & 55 & 55 \\
\cline { 2 - 4 } & Kesepadanan Lazim & 19 & 19 \\
\cline { 2 - 4 } & Generalisasi & 11 & 11 \\
\cline { 2 - 4 } & Partikularisasi & 6 & 6 \\
\cline { 2 - 4 } & Modulasi & 2 & 6 \\
\cline { 2 - 4 } & Kreasi Diskursif & 1 & \multicolumn{1}{c}{1} \\
\cline { 2 - 4 } & Kompresi Linguistik & $\mathbf{1 0 0}$ & $\mathbf{1 0 0}$ \\
\hline \hline
\end{tabular}

Peneliti membagi teknik penerjemahan yang muncul berdasarkan kategori kata tabu. Untuk kata tabu yang berhubungan dengan seks, teknik penerjemahan yang cenderung muncul adalah teknik delesi atau penghapusan. Dari 100 data kata tabu yang berhubungan dengan seks, 55 kata tabu tidak diterjemahkan/dihilangkan pada terjemahan bahasa Indonesianya. Misalnya pada data berikut.

\section{JS005}

You two sons of bitches are going to college!

Kalian berdua akan jadi anak kuliahan!

Frasa sons of bitches yang merupakan bentuk pelabelan dari penutur terhadap kedua mitra tuturnya dengan label yang buruk dihilangkan pada terjemahannya oleh penerjemah, padahal bisa saja penerjemah menerjemahkan frasa tersebut dengan kata bajingan atau berengsek, atau bisa jadi dengan nama hewan seperti anjing atau babi. Meskipun pesan yang terkandung dalam ungkapan tersebut tersampaikan ke bahasa sasarannya, penghilangan frasa tabu tersebut tentu saja berpengaruh pada nilai tabu yang terdapat pada versi bahasa Inggrisnya. Menurut peneliti, sah saja menerjemahkan kata tabu adalah hal yang wajar asalkan hal tersebut sesuai dengan konteks dan situasinya, karena pada film Indonesia sendiri, untuk genre film tertentu seperti aksi, kata tabu lumrah digunakan dalam dialognya.

Teknik penerjemahan berikutnya adalah kesepadanan lazim. Teknik kesepadanan lazim adalah teknik yang terjadi saat penerjemah menerjemahkan kata dari bahasa sumber dengan pilihan kata yang sepadan secara makna dengan kata tersebut dan lazim digunakan di bahasa sasaran. Teknik ini muncul sebanyak sembilan belas kali untuk kategori kata tabu yang 
berhubungan dengan seks. Penggunaan teknik kesepadanan lazim dapat dilihat pada data berikut.

\section{JS028}

He's the fucking Terminator!

Dia Terminator berengsek!

Pada data 22JS028, kata fucking diterjemahkan menjadi 'berengsek'. Kata berengsek memang lazim digunakan di Indonesia sebagai umpatan atau makian. Dari segi nilai, kata fucking dan berengsek sepadan dalam artian kata berengsek dapat mewakili situasi yang tergambarkan pada bahasa sumber. Kata fucking pada bahasa sumber menunjukkan ketidaksukaan penutur terhadap seseorang yang ia sebut terminator. Setelah diterjemahkan menjadi berengsek, pembaca tetap bisa merasakan ketidaksukaan dari penutur tersebut.

Selanjutnya, yaitu teknik generalisasi. Teknik ini terjadi saat penerjemah menerjemahkan kata dari bahasa sumber dengan kata yang lebih umum (superordinat), misalnya kata sepeda motor diterjemahkan menjadi kendaraan. Selain itu, teknik ini juga dapat terjadi saat penerjemah menerjemahkan kata yang cukup jelas di bahasa sumber dengan kata yang implisit di bahasa sasaran. Misalnya pada data berikut.

\section{JS068}

... or do you just get to watch people fuck?

... atau kau cuma menonton orang bercinta?

Kata fuck diterjemahkan menjadi 'bercinta'. Secara makna, kedua kata tersebut memiliki makna yang sama. Namun dari segi nilai, kata bercinta telah kehilangan nilai ketabuan dari kata fuck karena kata bercinta merupakan bentuk penghalusan nilai (eufemisme) untuk mengganti kata yang sepadan dan senilai dengan kata fuck.

Berbeda dengan teknik generalisasi, teknik partikularisasi terjadi saat penerjemah menerjemahkan kata umum di bahasa sumber menjadi kata yang lebih spesifik (subordinat). Pada beberapa kasus, teknik ini juga dapat disebut teknik eksplisitasi, yaitu saat penerjemah menerjemahkan istilah pengganti dengan kata aslinya. Dalam data kata tabu yang berhubungan dengan seks, teknik penerjemahan partikularisasi muncul sebanyak enam kali, contohnya pada data berikut.

\section{JS132}

Are you two fuckingaround at school again?

Kalian bikin onar lagi di sekolah?

Dalam ungkapan di atas, penutur memang bermaksud untuk mengatakan 'berbuat onar' dalam bahasa sumbernya. Namun bukannya menggunakan istilah messing around, penutur memilih istilah fucking around, artinya, penutur menggunakan istilah yang implisit. Saat diterjemahkan, penerjemah menerjemahkan frasa fucking around menjadi 'bikin onar' sesuai maksud penutur, artinya penerjemah mengeksplisitkan istilah yang diimplisitkan oleh penutur di bahasa sumber.

Seperti teknik partikularisasi, teknik modulasi juga muncul enam kali pada data. Teknik penerjemahan modulasi terjadi saat penerjemah mengubah sudut pandang, fokus, atau kategori kognitif, misalnya perubahan kalimat aktif menjadi kalimat pasif atau sebaliknya. Teknik modulasi yang muncul di data adalah sebagai berikut. 


\section{JS083}

Fuck you, brain!

Tololnya aku!

Pada ungkapan di atas, penutur di bahasa sumber mengumpat bagian tubuhnya, kemudian ungkapan tersebut diterjemahkan oleh penerjemah menjadi tololnya aku yang menunjukkan bahwa penutur menyalahkan dirinya sendiri. Terjadi perubahan sudut pandang yang awalnya di bahasa sumber sang penutur seolah-olah menyalahkan sesuatu, sedangkan pada bahasa sasaran penutur menyalahkan dirinya sendiri. Namun, meskipun terjadi perubahan sudut pandang, pesan sang penutur dapat tersampaikan karena kedua ungkapan tersebut bermakna sama.

Teknik kelima yang muncul adalah teknik kreasi diskursif. Teknik ini muncul sebanyak dua kali. Teknik kreasi diskursif adalah teknik yang terjadi saat penerjemah menerjemahkan kata dari bahasa sumber dengan kata yang sepadan sementara, tetapi keluar dari konteks. Contoh terjadinya teknik kreasi diskursif terdapat pada data berikut ini.

\section{SJ097}

That's Schmidt being a little bitch!

Itu Schmidt yang jadi gay murahan!

Frasa a little bitch pada ungkapan di atas diterjemahkan menjadi 'gay murahan'. Kata bitch pada ungkapan terebut sebenarnya merujuk pada wanita tunasusila, sedangkan kata gay merujuk pada seorang lelaki yang memiliki ketertarikan baik secara fisik, seksual, maupun perasaan kepada sesama lelaki. Kedua kata tersebut tidak berhubungan sama sekali. Oleh karena itu, penggunaan teknik penerjemahan kreasi diskursif kurang tepat digunakan karena pesan yang terkandung pada bahasa sumber tidak tersampaikan ke bahasa sasaran.

Teknik penerjemahan yang terakhir pada kategori kata tabu yang berkaitan dengan seks adalah teknik kompresi linguistik. Teknik ini hanya muncul satu kali. Teknik kompresi linguistik adalah teknik yang terjadi saat penerjemah menerjemahkan dengan mengurangi atau mensintesis unsur linguistik dalam suatu ungkapan pada bahasa sumber. Misalnya seperti pada data berikut ini.

\section{JS093B}

Fuck a 21 Jump Street, and fuck a Korean Jesus!

Persetan 21 Jump Street, dan Yesus Korea!

Terdapat dua kata fuck pada ungkapan bahasa sumber di atas, tetapi setelah diterjemahkan, hanya ada satu terjemahan dari kata fuck, yaitu kata fuck yang muncul pertama, sedangkan kata fuck kedua tidak diterjemahkan lagi. Dengan tidak diterjemahkannya kata fuck kedua, bukan berarti kata tersebut dihilangkan (menggunakan teknik delesi), tetapi karena repetisi kata fuck yang maknanya sama, penerjemah dapat menghilangkan terjemahan kata fuck kedua, jadi kata 'persetan' sudah dapat mewakili kedua kata fuck pada bahasa sumber. 
Tabel 3. Data Teknik Penerjemahan pada Kata Tabu yang Berhubungan dengan Ekskresi

\begin{tabular}{llcc}
\hline \hline Kategori & \multicolumn{1}{c}{ Teknik Penerjemahan } & Jumlah & Persentase \\
\hline \multirow{5}{*}{ Ekskresi } & Kesepadanan Lazim & 24 & 58,5 \\
\cline { 2 - 4 } & Partikularisasi & 9 & 22 \\
\cline { 2 - 4 } & Delesi & 4 & 9,8 \\
\cline { 2 - 4 } & Generalisasi & 3 & 7,3 \\
\cline { 2 - 4 } & Modulasi & 1 & 2,4 \\
\hline \hline & \multicolumn{1}{c}{ Total } & $\mathbf{4 1}$ & $\mathbf{1 0 0}$ \\
\hline
\end{tabular}

Untuk kategori kata tabu yang berhubungan dengan ekskresi, penerjemah cenderung menggunakan teknik penerjemahan kesepadanan lazim. Dari total 41 data, teknik kesepadanan lazim digunakan sebanyak 24 kali atau 58,5\%. Contoh penggunaan teknik kesepadanan lazim untuk menerjemahkan kata tabu yang berhubungan dengan ekskresi ada pada data berikut ini.

\section{JS006}

Shit! That's the Ghost!

Sial! Itu si Hantu!

Pada ungkapan di atas, kata shit pada bahasa sumber diterjemahkan oleh penerjemah menjadi 'sial' di bahasa sasaran. Shit pada ungkapan tersebut merupakan suatu bentuk umpatan, lalu saat diterjemahkan menjadi sial juga merupakan bentuk umpatan di bahasa Indonesia, jadi penggunaan teknik kesepadanan lazim pada ungkapan ini sesuai.

Berikutnya, yaitu teknik partikularisasi. Teknik ini digunakan sebanyak sembilan kali, salah satunya pada data berikut ini.

\section{JS047}

Now these kids take this shit...

Banyak mahasiswa mengonsumsi narkoba ini...

Pada ungkapan di atas, penutur memang bermaksud untuk mengatakan narkoba, namun dia mengganti kata drugs dengan shit, atau dengan kata lain, si penutur mengimplisit kata narkoba, namun saat diterjemahkan, penerjemah menerjemahkan kata shit dengan narkoba sehingga apa yang telah diimplisitkan penutur menjadi eksplisit kembali.

Kemudian ada teknik delesi. Teknik ini hanya digunakan empat kali dalam data khusus untuk kategori kata tabu yang berhubungan dengan ekskresi. Terjadinya teknik ini misalnya ditunjukkan pada data 22JS036 berikut:

\section{JS036}

Y'all see this shit?

Kalian lihat ini?

Yang penutur maksud dengan kata shit pada ungkapan di atas adalah kantor baru, namun ia mengimplisitkannya dengan menggunakan kata shit tersebut. Namun saat diterjemahkan, penerjemah menghilangkan terjemahan kata shit tersebut, padahal penerjemah memiliki pilihan untuk mengeksplisitkan kata shit, atau menerjemahkan kata shit secara literal.

Jika pada kategori kata tabu yang berhubungan dengan seks, teknik generalisasi lebih sering terjadi dibanding teknik partikularisasi, pada kategori kata tabu yang berhubungan 
dengan ekskresi, teknik generalisasi justru lebih sedikit terjadi, yakni hanya tiga kali. Contohnya pada data 22SJ015 berikut:

\section{JS015}

There's actual shit!

Ada kotoran juga!

Kata shit pada ungkapan di atas merujuk pada tahi burung, namun saat diterjemahkan, penerjemah menerjemahkannya menjadi kotoran, artinya, penerjemah mengubah istilah shit yang spesifik menjadi kotoran yang umum karena kotoran bisa bermakna selain tahi burung, bisa jadi kotoran tersebut bermakna lumpur, atau debu, dan lain-lain.

Teknik terakhir yang muncul pada kategori ini adalah teknik modulasi. Teknik ini muncul sekali, seperti pada data berikut ini.

\section{JS010}

Oh, that's bullshit, man!

Tidak mungkin, Bung!

Pada ungkapan di atas, terjadi perubahan dari kalimat positif ke kalimat negatif. Oleh karena itu, teknik yang digunakan penerjemah untuk ungkapan di atas adalah teknik modulasi.

Beralih ke kategori ketiga, yaitu kata tabu yang berhubungan dengan fungsi dan anggota tubuh. Pada data, kategori ini muncul sebanyak 12 kali dengan teknik penerjemahan yang cukup beragam, seperti yang ditampilkan pada tabel 4 berikut

Tabel 4. Data Teknik Penerjemahan pada Kata Tabu yang Berhubungan dengan Bagian dan Fungsi Tubuh

\begin{tabular}{cllc}
\hline \hline Kategori & \multicolumn{1}{c}{ Teknik Penerjemahan } & Jumlah & Persentase \\
\hline & Generalisasi & 6 & 50 \\
\cline { 2 - 4 } & Partikularisasi & 1 & 8,3 \\
\cline { 2 - 4 } Fungsi dan Anggota Tubuh & Delesi & 1 & 8,3 \\
\cline { 2 - 4 } & Kesepadanan Lazim & 1 & 8,3 \\
\cline { 2 - 4 } & Modulasi & 1 & 8,3 \\
\cline { 2 - 4 } & Adaptasi & 1 & 8,3 \\
\cline { 2 - 4 } & Reduksi-Kesepadanan Lazim & 1 & 8,3 \\
\hline \hline
\end{tabular}

Pada kategori kata tabu yang berhubungan dengan fungsi dan anggota tubuh, terdapat dua teknik penerjemahan yang belum muncul pada dua kategori sebelumnya, yaitu teknik adaptasi dan teknik kombinasi antara reduksi dan kesepadanan lazim. Teknik adaptasi terjadi saat penerjemah mengganti unsur budaya pada bahasa sumber dengan unsur budaya yang mempunyai sifat yang sama pada bahasa sasaran. Contohnya seperti pada data berikut ini.

\section{JS075}

Stop being a pussy ...

Jangan jadi banci ... 
Kata pussy merupakan salah satu sebutan untuk kelamin wanita, tetapi dalam ungkapan di atas, kata tersebut berarti 'pengecut' atau 'penakut'. Dengan kata lain, penutur menggunakan istilah pussy untuk mengatakan sifat penakut/pengecut dan hal tersebut lazim dilakukan di masyarakat bahasa sumber. Setelah diterjemahkan, kata pussy berubah menjadi 'banci' yang mana pada bahasa sasaran, istilah banci juga memiliki makna konotasi penakut/pengecut. Terjadinya pergantian kata pussy menjadi 'banci' menunjukkan adanya pergantian unsur budaya pada bahasa sumber dengan unsur budaya yang memiliki sifat yang sama pada bahasa sasaran. Oleh karena itu, pada ungkapan ini, penerjemah menggunakan teknik adaptasi.

Teknik berikutnya yaitu teknik kombinasi reduksi dan kesepadanan lazim. Teknik kombinasi terjadi akibat adanya gabungan kata (frasa atau klausa) yang harus diterjemahkan menjadi satu kesatuan karena gabungan kata tersebut memiliki satu makna. Kemunculannya pada data adalah sebagai berikut.

\section{JS037}

And I got a big-ass raise

... aku mendapat dana besar ...

Pada ungkapan di atas, frasa big-ass berfungsi sebagai epitet atau kata sifat yang menjelaskan kata benda raise. Penambahan kata ass setelah kata big bermakna bahwa besar yang dimaksud oleh penutur bukan lagi besar biasa, melainkan luar biasa besar. Namun pada terjemahannya, penerjemah hanya menerjemahkan big-ass menjadi 'besar', itu artinya penerjemah hanya menerjemahkan kata big dengan teknik kesepadanan lazim, sedangkan kata ass diabaikan, atau dengan kata lain, terjadi teknik reduksi atau delesi sehingga pada terjemahan frasa big-ass, terjadi kombinasi antara teknik reduksi dan kesepadanan lazim.

Kategori terakhir adalah kata tabu yang berhubungan dengan agama. Kategori ini hanya muncul sebanyak 7 kali pada data dengan 3 teknik penerjemahan, yaitu teknik adaptasi, delesi, dan kesepadanan lazim. Untuk lebih jelasnya, data ditampilkan pada tabel berikut ini.

Tabel 5. Data Teknik Penerjemahan pada Kata Tabu yang Berhubungan dengan Agama

\begin{tabular}{clcc}
\hline \hline Kategori & \multicolumn{1}{c}{ Teknik Penerjemahan } & Jumlah & Persentase \\
\hline \multirow{3}{*}{ Agama } & Kesepadanan Lazim & 5 & 71,4 \\
\cline { 2 - 4 } & Delesi & 1 & 14,3 \\
\cline { 2 - 4 } & Adaptasi & 1 & 14,3 \\
\hline & Total & $\mathbf{7}$ & $\mathbf{1 0 0}$ \\
\hline
\end{tabular}

Pada kategori kata tabu yang berhubungan dengan agama, teknik adaptasi juga muncul satu kali, yaitu pada data berikut ini.

\section{JS033}

Holy Moses!

Astaga!

Moses merupakan nama Nabi Musa dalam bahasa Inggris. Pada ungkapan tersebut, Moses berperan sebagai interjeksi atau kata seru. Penutur mengucapkan ungkapan tersebut sebagai wujud ekspresi terkejut. Saat diterjemahkan, penerjemah mengganti frasa Holy Moses dengan 'astaga'. Frasa Holy Moses dan astaga pada ungkapan tersebut memiliki sifat yang 
sama, yakni menunjukkan keterkejutan. Namun. istilah nama nabi tidak lazim digunakan oleh masyarakat di bahasa sasaran. Oleh karena itu, penerjemah menggantinya dengan istilah yang lazim digunakan untuk menunjukkan keterkejutan, yaitu astaga. Maka terjadilah teknik penerjemahan adaptasi.

Untuk menentukan metode penerjemahan dan ideologi penerjemah dari terjemahan kata tabu pada film 22 Jump Street diperlukan penghitungan teknik penerjemahan yang terjadi secara keseluruhan. Lebih lanjut, jumlah teknik penerjemahan dan persentasenya dapat dilihat pada tabel berikut ini.

Tabel 6. Teknik Penerjemahan

\begin{tabular}{clcc}
\hline \hline No & Teknik Penerjemahan & Jumlah & Persentase \\
\hline 1 & Delesi & 61 & 38,1 \\
\hline 2 & Kesepadanan Lazim & 49 & 30,6 \\
\hline 3 & Generalisasi & 20 & 12,5 \\
\hline 4 & Partikularisasi & 16 & 10 \\
\hline 5 & Modulasi & 8 & 5 \\
\hline 6 & Adaptasi & 2 & 1,3 \\
\hline 7 & Kreasi Diskursif & 2 & 1,3 \\
\hline 8 & Kompresi Linguistik & 1 & 0,6 \\
\hline 9 & Reduksi-Kesepadanan Lazim & 1 & 0,6 \\
\hline & Total & $\mathbf{1 6 0}$ & $\mathbf{1 0 0}$ \\
\hline \hline
\end{tabular}

Dari tabel di atas, dapat dilihat bahwa penerjemah cenderung menghilangkan kata tabu dalam terjemahannya, yakni sebanyak 61 kali atau 38,1\% dari data keseluruhan. Kemudian, penerjemah menggunakan teknik kesepadanan lazim sebanyak 49 kali atau 30,6\%. Teknik generalisasi ditemukan digunakan sebanyak 20 kali atau 12,5\% sedangkan teknik partikularisasi ditemukan digunakan sebanyak 16 kali atau 10\%. Teknik modulasi muncul sebanyak 8 kali atau $5 \%$. Teknik adaptasi dan kreasi diskursif masing-masing digunakan sebanyak 2 kali atau 1,3\% dan teknik kompresi linguistik serta teknik kombinasi reduksi-kesepadanan lazim masingmasing digunakan sekali.

Secara umum, penerjemah cenderung menghilangkan kata tabu dalam terjemahannya yang mengakibatkan hilangnya nilai ketabuan pada bahasa sasaran, itu artinya penerjemah mengubah pesan dari bahasa sumber. Pada saat yang sama, penerjemah juga berusaha mencari padanan istilah di bahasa sasaran yang sesuai dengan bahasa sumber. Oleh sebab itu, dapat disimpulakan bahwa metode penerjemahan dalam terjemahan kata tabu karya penerjemah FatHur adalah metode penerjemahan adaptasi.

Pada metode penerjemahan adaptasi, penerjemah berusaha mengubah budaya bahasa sumber dalam bahasa sasaran. Ciri lain dari metode ini adalah terjemahan tidak terikat dengan pesan di bahasa sumber. Hal ini dapat dilihat dari kecenderungan penerjemah yang menghilangkan kata tabu dalam terjemahannya.

Penentuan metode penerjemahan kata tabu karya FatHur ini juga menjadi acuan dalam menentukan ideologi yang dianut oleh penerjemah. Hal ini dikarenakan metode penerjemahan kata tabu karya FatHur adalah metode penerjemahan adaptasi dan secara langsung dapat diputuskan bahwa ideologi yang dianut oleh FatHur adalah ideologi pelokalan. Dengan kata lain, penerjemah cenderung berpihak pada bahasa sasaran. Penghilangan kata tabu dari 
terjemahannya dapat menjadi salah satu indikasi dari keberpihakan penerjemah terhadap bahasa sasaran karena secara umum kata tabu tidak digunakan secara bebas dalam percakapan di masyarakat bahasa sasaran. Namun, perlu ditekankan bahwa metode penerjemahan dan ideologi penerjemah yang dinilai pada penelitian ini hanya terbatas pada penerjemahan kata tabu, bukan penilaian teks terjemahan secara keseluruhan.

Penghilangan kata tabu dalam terjemahan ini dapat diakibatkan oleh beberapa hal, misalnya pengaruh budaya masyarakat bahasa sasaran, kurangnya perbendaharaan kata tabu penerjemah, dan perbedaan struktur gramatikal kedua bahasa. Budaya bahasa sasaran dapat memengaruhi penerjemah untuk menghilangkan kata tabu pada terjemahannya. Penggunaan kata tabu yang tidak lazim bagi masyarakat di bahasa sasaran akan membuat terjemahan tersebut tidak dapat diterima oleh pembaca di bahasa sasaran karena tidak sesuai dengan budaya mereka. Selain budaya, kurangnya perbendaharaan kata tabu penerjemah juga dapat menjadi alasan penghilangan kata tabu dalam terjemahan tersebut karena penerjemah tidak dapat menemukan padanan yang sesuai terhadap kata tabu tersebut di bahasa sasaran. Kemungkinan terakhir yang dapat menjadi alasan penghilangan kata tabu pada terjemahan tersebut adalah karena adanya perbedaan struktur gramatikal antara bahasa sumber dan bahasa sasaran, misalnya struktur frasa nomina. Pada bahasa sumber struktur frasa nomina adalah menerangkanditerangkan atau dengan kata lain, kata sifat yang berperan sebagai penjelas mendahului kata benda yang dijelaskan, sedangkan pada bahasa sasaran, struktur gramatikal frasa nomina adalah diterangkan-menerangkan, artinya, kata benda ditulis terlebih dahulu lalu diikuti oleh kata sifatnya.

\section{SIMPULAN}

Dari hasil penelitian ini dapat disimpulkan bahwa ideologi yang dianut penerjemah dalam menerjemahkan kata tabu pada film 22 Jump Street adalah idelogi pelokalan atau domestikasi. Hal ini berdasarkan kecenderungan penerjemah yang menghilangkan terjemahan kata tabu sehingga makna nilai ketabuan pada bahasa sasaran hilang. Selain itu, adanya usaha penerjemah untuk menemukan padanan kata tabu pada bahasa sasaran juga semakin menegaskan keberpihakan penerjemah terhadap bahasa sasaran. Adapun penghilangan kata tabu pada bahasa sasaran dapat disebabkan oleh tiga hal, yakni pengaruh budaya, kurangnya perbendaharan kata tabu, dan perbedaan struktur gramatikal kedua bahasa.

Pada akhirnya, penelitian ini memberikan gambaran bagaimana karya seorang penerjemah dapat menunjukkan keberpihakannya terhadap bahasa sumber atau bahasa sasaran. Pembaca juga dapat melihat gambaran bagaimana penggunaan teknik penerjemahan berpengaruh terhadap metode penerjemahan dan ideologi penerjemah. Sementara itu, bagi peneliti lain, penelitian ini dapat menjadi acuan untuk melakukan penelitian lanjutan, misalnya mengaitkan ideologi penerjemah dengan gender atau mengaitkan ideologi penerjemah dengan suku atau daerah asal penerjemah.

\section{CATATAN}

Penulis berterima kasih kepada mitra bebestari yang telah memberikan masukan yang berharga untuk meningkatkan kualitas makalah ini. 


\section{DAFTAR PUSTAKA}

Bell, R. T. (1991). Translation and translating: Theory and practice. New York: Longman.

Hoed, B. H. (2006). Penerjemahan dan kebudayaan. Jakarta: Pustaka Jaya.

Kusmayani, A. (2013). Analisis teknik penerjemahan istilah tabu dalam film berjudul The Hurt Locker dan pengaruhnya terhadap kualitas terjemahan. (Tesis), Universitas Sebelas Maret, Surakarta.

Mazi-Leskovar, D. (2003). Domestication and foreignization in translating American prose for Slovenian children. Meta,48(1).

Molina, L. \& Amparo, H. A. (2002). Translation techniques revisited: A dynamic and functionalist approach. Meta, 7(4).

Nababan, M. dkk. (2012). Pengembangan model penilaian kualitas terjemahan. Kajian Linguistik dan Sastra,24(1).

Newmark, P. (1988). A textbook of translation. London: Prentice Hall International.

Permadi, C. B. (2017). Translation of taboo words in the Spongebob Movie Sponge out of Water and their Indonesian subtitles. (Skripsi), UIN Syarif Hidayatullah, Jakarta.

Pratama, A.D.Y. (2016). Taboo words and their translation in subtitling: A case study in The Help. Retorika: Jurnal ilmu Bahasa,2(2).

Shanti, Ni M. W. (2014). The translation of taboo words into Indonesian in The Fast \& Furious Tokyo Drift and Fast Five Movie. Humanis, 6(2).

Venuti, L. (1995). The translator's invisibility: A history of translation. London \& New York: Routledge.

Wardhaugh, R. (2006). An introduction to Sociolinguistics (Edisi ke-5). Victoria: Blackwell Publishing.

Yamayanti, K. P. (2015). The English-Indonesian translation of taboo words in Ted Movie. (Skripsi), Universitas Udayana, Denpasar. 